ELORE (ISSN 1456-3010), vol. 17 - 2/2010.

Julkaisija: Suomen Kansantietouden Tutkijain Seura ry.

[http://www.elore.fi/arkisto/2_10/lukin_2_10.pdf]

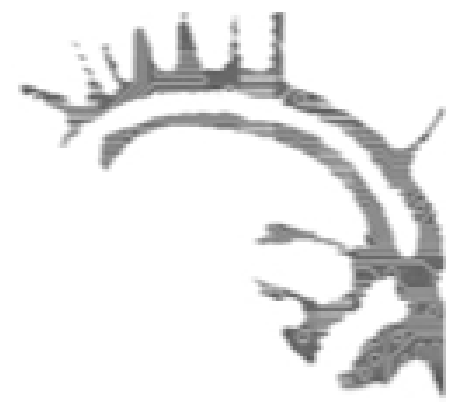

KiRJA-ARVIO

\title{
ArgumentTIEn KirJo
}

VÄISÄNEN, JARNO 2008: Accountable Arguments. A Rhetorical and Ethnomethodological Approach to Local Level Argumentation on the Rearrangement of Land and Water Rights in the Saami Area. Joensuun yliopiston humanistisia julkaisuja n:o 53. Joensuu: University of Joensuu. 194 sivua.

\section{$\underline{\text { Karina Lukin }}$}

Jarno Väisäsen väitöskirja Accountable Arguments ottaa härkää sarvista. Alkuperäiskansojen maa- ja vesioikeudet sekä kulttuuriset oikeudet ovat herättäneet kiihkeitä keskusteluja maailman ympäri eivätkä Pohjoismaiden viime vuosikymmenten keskustelut ole olleet rauhallisimpia. Yhtenä pohjoismaisen keskustelun taustatekijänä on ollut Kansainvälisen työjärjestön ILOn sopimus 169 vuodelta 1989. Sopimus, jonka Pohjoismaista ainoastaan Norja on ratifioinut, korostaa alkuperäiskansojen oikeutta osallistua päätöksentekoon ja jatkaa maankäyttöä perinteisin tavoin. Siinä korostetaan myös maan omistamisen tärkeyttä. ILOn sopimus 169 on myös yksi Väisäsen tutkimuksen konteksteista: teksti, joka edustaa eri asioita tutkimuksessa esiintyville ihmisille.

Keskustelut oikeudesta maahan ja elinkeinoihin ovat olleet saamelaisalueilla räiskyviä, sillä maa ei ole loputtomiin jaettavissa. Kiivaus johtuu myös paikallistason monenlaisista ajassa ja paikassa muuttuneista ja muuttuvista etnisistä ja elinkeinoihin liittyvistä asetelmista. Väisäsen tutkimus tuo kiitettävällä tavalla esiin niin kansallisvaltioiden kuin tutkimuskylien välisiä eroja, jotka eivät suinkaan ole tutkitulla alueella pieniä. 


\section{NiUKKAA TEKSTIÄ}

Keskustelun kiivaus ja asian arkaluonteisuus paikallistasolla näkyy myös tutkimuksessa itsessään. Väisänen jättää mainitsematta kenttätyökohteidensa oikeat nimet eikä merkitse seitsemää tutkimuskylää kartalle. Kylät on nimetty uudestaan ja niiden sijainti ilmoitetaan ainoastaan summittaisesti, toki niin että esimerkiksi merkittävät hallinnolliset tai muut yhteiskunnalliset tekijät pystytään ottamaan huomioon. Väisästä käy kuitenkin kiittäminen siitä, että kireällä ilmapiirillä ei ole mässäilty tutkimuksessa, minkä olisi voinut tehdä esimerkiksi kenttätyötä kuvaavassa luvussa. Sen sijaan hän käy lyhyesti mutta tarpeen vaatimalla laajuudella läpi kenttätöiden kulkua, keskusteluja ja valitsemiaan metodeja ja perustelee niitä.

Vähäsanaisuus on muutoinkin tämän tutkijan tyyli. Teoksessa on kauttaaltaan kerrottu vain kaikkein välttämättömin tieto, jotta asia olisi lukijalle ymmärrettävä. Tämäkin ilmaistaan tiiviisti ja toistoa on vältetty viimeiseen asti. En ole varma, johtuuko edellä mainitusta vai tutkimuksen harmittavan tökeröstä englannista, että Väisäsen työ muistuttaa ilmaisultaan välistä Kaurismäen elokuvaa. Asiat tipahtavat lukijan eteen lyhyin tokaisuin ja kuva täydellistyy otos otokselta. Ainakin suomalainen lukija tottuu tähän nopeahkosti.

\section{OPINNÄYTTEEN RAKENTEIDEN PUITTEISSA}

Accountable Arguments on rakenteeltaan opinnäytetyö, niin kuin pitäkikin. Johdannossa Väisänen esittelee tutkimuksen lähtökohdat, metodit, taustatietoja maa-, vesija kulttuurioikeuksista. Hän kertoo myös kenttätöistä ja tutkimusaineiston rakentumisesta ja jatkaa esittämällä seuraavissa luvuissa tutkimuksen kaksi metodologista lähtökohtaa: retorisen ja etnometodologisen. Molempien esittely on tyyliin kuuluen niukkaa mutta osoittaa, että kirjoittaja tuntee lähestymistapansa. Varsinainen analyysi alkaa jo luvussa neljä, jolloin lukija on hieman yllättynyt. Itse jäin ainakin kaipaamaan vielä lisää taustalukuja ja etenkin Pohjoismaiden ulkopuolinen lukija kaivannee niitä vielä enemmän. Väisänen ei esittele ennen analyysejä tutkimusalueen yleisempää historiaa, mikä liittynee historian kiisteltyyn luonteeseen. Yleisemmän historian esittely olisi kuitenkin helpottanut analyysilukujen lukemista. Vaikka Väisänen esittelee itse analyysiluvuissa kunkin kylän relevantteja historiallisia taustoja, yhdistää kyliä esimerkiksi kansallisvaltioiden rajakiistat ja yleinen saamelais- ja alkuperäiskansaliikehdintä. Kyliä myös erottavat monet seikat, jotka olisi voinut mainita taustana: saamelaiskulttuurin monimuotoisuus, kveenien, meänkielisten ja Suomen lappilaisten tai lantalaisten suhteet saamelaisväestön kanssa. Myös lestadiolaisuus kuuluu tällaisiin yleisiin tekijöihin, jota Väisänen pohtii kyllä analyysien puitteissa.

Taustaluvussa olisi voinut esitellä myös sitä tutkimusta, joka liittyy Pohjoismaiden pohjoisen maaoikeuksiin tai saamelaisten tutkimukseen. Nyt tutkimus ei sijoitu niiden joukkoon, mikä on varmaan tarkoituskin. Aiempi tutkimus on ollut vähintäänkin yhtä kiivasta kuin paikallistason keskustelut. Aiemmat tutkimukset eivät silti 
rajoitu ainoastaan niihin harvoihin, jotka Väisänen mainitsee esikuvikseen. Niiden esittely laajemmin olisi terävöittänyt Väisäsen projektin erityisyyttä, koska se todella on huomattava saamelaispolitiikan tutkimuksessa. Nyt tutkimus asettuu eksplisiittiseesti ainoastaan osaksi etnometodologista projektia.

Itse analyysi on ilahduttavan selkeää ja suorasanaista. Tutkimuksessa käydään kukin kylä tai kyläryhmä läpi vuorotellen. Väisänen esittelee lyhyesti kunkin paikan kenttätyön erityispiirteitä ja keskustelujen keskeiset teemat. Tarvittaessa hän myös syventää metodologista apparaattiaan ja keskustelee kiinnostavalla tavalla etnometodologien kanssa. Analyysissa Väisänen onnistuu raottamaan maa- ja vesikysymysten ongelman ydintä hyvin konkreettisesti: yleisellä tasolla määritellyt oikeudet ja velvollisuudet pirstoutuvat paikallistasolla niin monenlaisiksi ja monitahoisiksi kiistoiksi, ettei ILOn sopimus tunnu enää antavan toimivia lähtökohtia tai vastauksia. Kaiken lisäksi pirstoutumista ei tapahdu ainoastaan paikallisesti, vaan myös ajallisesti keskustelujen kehittyessä odotettuihin ja odottamattomiin suuntiin.

\section{MONIEN KOHTAAMISTEN KIRJO}

Vaikka Väisänen oli kenttätyöntekijänä ryhmähaastatteluissaan itsepäisesti pyrkinyt käyttämään yhtäläistä kysymysrunkoa, keskusteluista on noussut esiin eri aiheita. Monipaikkainen kenttätyö osoittautuu hyvin onnistuneeksi valinnaksi, mikä käy ilmi jo kahta ensimmäistä analysoitua kylää vertailtaessa. Vaikka nämä Ruotsin puolella sijaitsevat kylät ovat suhteellisen lähellä toisiaan, niiden etninen koostumus ja argumentaation keskiöt eroavat huomattavasti toisistaan. Paitsi paikallisuutta, tutkimuksessa pohditaan myös ajan vaikutusta argumentaatioon. Väisänen teki yhdessä Ruotsin puolella sijaitsevassa kylässä kenttätyötä sekä vuonna 2000 että 2002. Vaikka kylässä keskusteltiinkin toisenlaisissa, lähes päinvastaisissa olosuhteissa, samat aiheet löytyivät molempina vuosina.

Koska Väisäsen kenttätyöt ulottuvat niin monenlaisiin konteksteihin, ylettyy analyysi niin ikään moninaisiin teemoihin. Käsitellyiksi tulevat muun muassa saamelaisten ja heidän jutamisreittiensä varrella olevien kyläläisten keskinäiseen avunantoon perustuneet väärtisuhteet, Lapinkylien vaikutukset nykyisiin argumentteihin, eri saamelaiselinkeinojen epätasa-arvoisuus saamelaispolitiikassa ja erilaisten asiantuntijoiden käyttäminen argumentaatiossa tai asiantuntijan roolin merkitys maa- ja vesioikeuskeskusteluissa. Teemojen kirjavuutta ei voi pitää huonona puolena - nehän nousevat Väisäsen tekemistä ryhmähaastatteluista. Väisänen myös kokoaa pirstaleiselta vaikuttavaa kuvaa yhteen hienosti loppuluvussa pohtimalla etnisyyttä, kulttuurieroja ja paikallistason suhdetta makrotason prosesseihin. Vaikka etnisyys nousee hieman yllättäen näin keskeiseen osaan, tutkija kyllä osoittaa tietävänsä, mistä puhuu. Sen olisi voinut nostaa esiin jo aiemmin, vaikka Väisänen pitäneekin etnisyyden keskeisyyttä yhtenä tutkimustuloksena eikä lähtökohtana.

Väisänen kommentoi niukalti väitöskirjassaan omia henkilökohtaisia näkemyksiään maa- ja vesiasioista tai kokemuksiaan kiivaista keskusteluista, mikä ei sinänsä ole 
Karina Lukin: Argumenttien kirjo

tarpeenkaan. Verhoa raotetaan vasta viimeisillä sivuilla, joissa tutkija tietää tutkimustulostensa - erityisesti paikallistason moninaisuuden loputtomuuden - ärsyttävän monia paikallistasoa edustavia henkilöitä. Nämä ihmiset haluavat pirstaloituneen kuvan sijasta nähdä asiat selkeinä, jotta ILOn sopimus voitaisiin ratifioida. Tutkija onkin onnellinen siitä, että vastaavaa kritiikkiä on sadellut kaikilta tahoilta, sillä väitöskirjan tarkoitus ei ollut uuden makrotason arvion rakentaminen. Tutkimuksen linjana on ollut tuoda esiin moninaisia teemoja ja erilaisia keskusteluja. Tämä tukee Väisäsen perusargumenttia tai -ongelmaa, jonka mukaan "tasapuolinen kohtelu edellyttää erilaista kohtelua joissain tapauksissa" (s. 181).

Filosofian maisteri Karina Lukin valmistelee folkloristiikan väitöskirjaa nenetsien kerronnasta ja paikkasuhteesta Helsingin yliopistossa. 